\title{
LABORATORY OF BIOMEDICAL AND
}

\section{ENVIRONMENTAL SCIENCES}

UNIVERSITY OF CALIFORNIA

900 VETERAN AVENUE

LOS ANGELES, CALIFORNIA
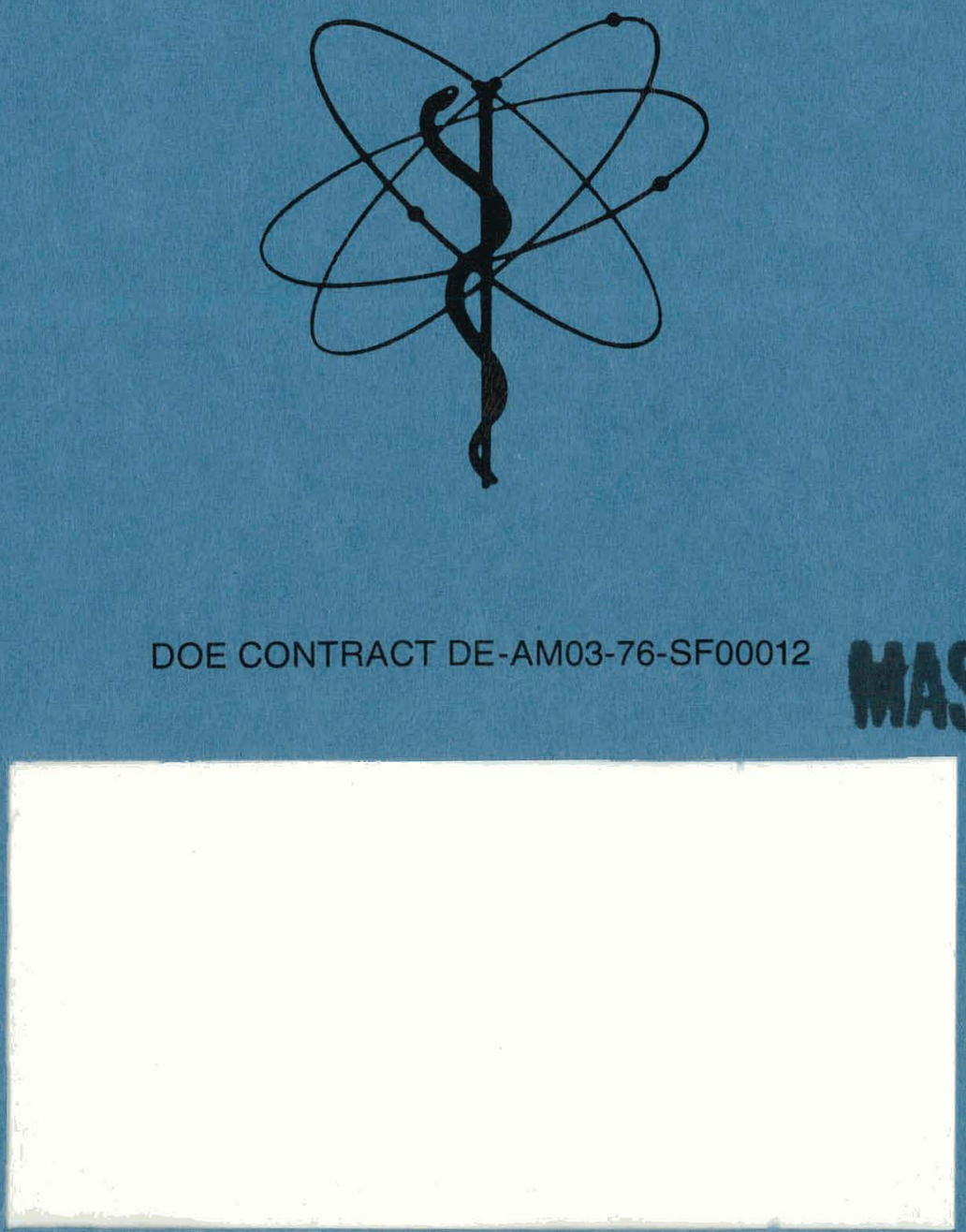


\section{DISCLAIMER}

This report was prepared as an account of work sponsored by an agency of the United States Government. Neither the United States Government nor any agency Thereof, nor any of their employees, makes any warranty, express or implied, or assumes any legal liability or responsibility for the accuracy, completeness, or usefulness of any information, apparatus, product, or process disclosed, or represents that its use would not infringe privately owned rights. Reference herein to any specific commercial product, process, or service by trade name, trademark, manufacturer, or otherwise does not necessarily constitute or imply its endorsement, recommendation, or favoring by the United States Government or any agency thereof. The views and opinions of authors expressed herein do not necessarily state or reflect those of the United States Government or any agency thereof. 


\section{DISCLAIMER}

Portions of this document may be illegible in electronic image products. Images are produced from the best available original document. 
LABORATORY OF BIOMEDICAL AND ENVIRONMENTAL SCIENCES

900 VETERAN AVENUE

UNIVERSITY OF CALIFORNIA, LOS ANGELES, CALIFORNIA 90024

These studies were supported by Contract DE-AMO 3-76-SF00012 between the U.S. Department of Energy and the University of California

Prepared for U.S. Department of Energy under Contract DE-AM03-76-SF00012

LEGAL CONSIDERÄTIOINS INVOLVING CHEMICAL CONTROL OF IRON AND OTHER DEFICIENCIES IN PLANTS Arthur Wallace and Yasser $S$. Samman This book was prepared as an account of work sponsored by an ageney of the United States Governinent Neither the United States Government nor any agency thereof, nor any of their employees. makes any completeness, or ysefuniness of or assumes any lejal liability of responsibility for the accuracy. represents that is use would not intringe privaty or poratus. product, or process disclosed. or

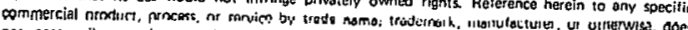


LEGAL CONSIDERATIONS INVOLVING CHEMICAL CONTROL OF IRON AND OTHER DEFICIENCIES IN PLANTS

KEY WORDS: Toxicities, zinc, chelates, foliar sprays, manganese.

Arthur Wallace and Yasser S. Samman*

Laboratory of Biomedical and Environmental Sciences

University of California, Los Angeles 90024

*on leave from Riyad University, Riyad, Saudi Arabia

$\underline{\text { ABSTRACT }}$

The authors are aware of four cases of lawsuits involving use of chelating agents in plant nutrition. Three of them involved use of iron. One concerned addition of FeDTPA to nursery trees in containers. No damages were paid and the conclusion was that the recommendation for use of the chelate was correctly made and no neglect was involved. one case involved foliar application of FeHEDIA to potatoes in July by airplane. The recomended rate was used but with less water than recommended to accommodate aerial application. The case was settled out of coint. Another case not involving iron chelate was with ZnEDTA and MEDTA with $\mathrm{Fe}$ as $\mathrm{FeSO}_{4}$ later as a foliar spray. The $\mathrm{Zn}$ and MIEDTA were applied as a band 8 inches $(20 \mathrm{~cm})$ on both sides of nursery tree rows just as the buds that had been placed in the fall began growing in the spring. Some 208 of the trees died in groups of $10,20,30$ or $s 0$ and onsentively in the rows. The case is not yet settled. In the fourth case, many tomato transplants died when the transplanting was done with about $120 \mathrm{ml}$ per plant of transplant solution containing besides $\mathrm{N}, \mathrm{P}$ and $\mathrm{K}$, about $19 \mathrm{mg} \mathrm{Zn}$ as ZnEDIA, $14 \mathrm{mg} M$ as MnEDTA and $7 \mathrm{mg}$ Fe as FeHEDTA. This case also is not yet settied. Cases such as these will probably discourage use of chelating agents in plant nutrition even if the chelating agents were not the damaging agent. Not enough developmental work was done on the potential toxicities from metal chelates. This trend to lawsuits makes it even more important to solve imn chlorosis problems via plant breeding.

Case 1. Iron DIPA applied to container plants.

Iron DTPA was applied to container plants in a nursery following recommendation by a laboratory. The recommendation was not necessarily 
high, however. Plants started to die soon thereafter. This prompted us to determine if young citrus trees in containers would tolerate high levels of FeDTPA and other iron chelates (Wallace and Mueller, 1972). In that test, one-year old seedlings of rough lemon and trifoliate orange, previously potted into 500-g quantities of yolo loam soil (pH 5.7) or with the same soil to which $58 \mathrm{CaCO}_{3}$ (powdered USP) had been mixed, were used in the study. The high level of $\mathrm{CaOO}_{3}$ was to simulate a calcareous soil of $\mathrm{pH} 7.5$. Both plant species are commonly used for rootstocks for citrus and the latter is subject to some micronutrient deficiencies. Before the start of the test, the plants were cut off $5 \mathrm{~cm}$ above the soil and applications of $100 \mathrm{ml} / \mathrm{pot}$ of $0,15,75,150$, and $300 \mathrm{ppm} \mathrm{Fe}$ in triplicate as FeEDIA (ferric ethylenediamine tetraacetate), FeDTPA (ferric diethylenetriamine pentaacetate), and FeEDDHA (ferric ethylenediamine di o-hydroxyphenyl acetate). were made weekly for 16 consecutive weeks to separate ontainers. The rates far exceeded levels used to correct Fe deficiency and greatly exceeded levels heretofore studied. Ordinarily $2 \mathrm{ppm} \mathrm{Fe}$ in soil as a chelate is sufficient to correct Fe deficiency, but each application of the above highest rate was equivalent to $60 \mathrm{ppm} F e$ in soil per application and the application was made 16 times. The pots had bottom drain holes so that the levels did not greatly build up. The plants received $50 \mathrm{ppm}$ of $\mathrm{N}$ on the dry weight of soil basis as $\mathrm{NH}_{4} \mathrm{NO}_{3}$ four different times during the test.

The limed soil resulted in yield depression for each species and this may be due to Fe deficiency. The Fe chelates tended to overcome the Fe deficiency, but their ability to increase the Fe content of leaves was surprisingly small. The plants seemed to be resistant to large increases in Fe as result of the treatments. The 2 lowest levels of FEEDTA and the lowest level of FeDTPA had relatively little effect on increasing $\mathrm{Fe}$ in leaves and this is consistent with their low stability constants in relationship to FeEDDHA.

These results indicate that it is very unlikely that rates of $\mathrm{Fe}$ chelates which are used to suply $\mathrm{Fe}$ to this type of plant material would cause any toxic effects on the plants directly as a result of the chelating agents.

Following are excerpts from the legal decisions concerning the nursery:

"In this appeal we must determine the proper standard of care a soil and plant laboratory must use in furnishing information to its customers.

The plaintiff/appellant (Nursery) argues that the "reasonable man" test is the proper standard of care to be applied to this case. The defendant/appellee (Lab) takes the position that a plant laboratory is in a class of professional consultants and that any negligence claim against them must be measured by the professional standard of care existing within the comminty. 
The trial court rendered the judgment upon the following grounds:

It is the view of the court that the Plaintiff must establish that the Defendant failed to conform with a standard of care existing within the commuity. There is absolutely no evidence brought to the court's attention indicating any opinion by a qualified expert that the advice given by Defendant breached any existing standard of care. Absent such an opinion, there is no evidence showing a breach of duty owed by the Defendant to the Plaintiff.

The Nursery appeals from this judgment and the denial of its motion for reconsideration. The Nursery claims the court erred in granting sumary judgment for the following reasons:

1. The proper standard of care by which the Lab's negligence should be judged is the reasonable man test and not the more demanding test of the prevailing commuity standard as applied in professional malpractice cases.

2. The conflict in the professional opinions by the respective party experts relative to the proper method of diagnosing the particular plant disease raised a genuine issue of material fact which bars the granting of a motion for summary judgment.

3. The Nursery under the provisions of the Restatement (Second) of Torts 5552 established a prima facie case of negligence against the Lab when it failed to inform the Nursery on the proper methods to combat a condition known as "iron toxicity" which was destroying the Nursery's potted plants.

The facts necessary for the determination of this appeal disclose that the Nursery is in the business of raising plants for commercial sale with an operation of approximately 5,000 containers and some field-grown stock. The Lab provides professional assistance to nurserymen and offers a wide variety of professional services ranging from soil, plant and water analysis to field calls and extended area visitations. The parties had a prior business relationship dating back to 1967 or 1968, whereby the Lab provided recommendations on proper fertilization and soil mix for the Nursery's container stock. The problem which t.riggered this litigation arose when the Nursery, by a letter dated May 25, 1970, asked the $\mathrm{Lab}$ for advice on the prevention of yellowing leaves in the Nursery's container grown stock. The Lab replied by letter dated June 8, 1970, with a pertinent recommendation that iron chelate be added to the fertilizer solution. The iron chelate was implemented with the watering on Jume 10, 1970, and approximately one week later the plants began looking more unhealthy.

On June 25, 1970, the Lab was advised by phone that the Nursery was encountering leaf burn problems. The Lab recosmended leaching the 
plants with clear water to remove any contaminants and requested soil and leaf samples for examination. The Iab received a soil sample from the Nursery on Jume 29, 1970, and leaf and water samples were received the following day. The Lab report, dated July 1, 1970, found the problem "which you have recently encountered appears to be due to sudden and extreme rate of fertilizer application with nitrogen being the primary element found in excess. The formula which has been provided and presumably has been in use could not possibly result in values in the range found, if the proportioner is operating in a normal manner." The report further stated:

Although the incidence of injury coincided in some degree with the application of iron, we cannot feel that this was responsible in view of the data obtained. It appears quite certain from data and our past experience that the problem is one of extreme concentration of fertilizer being applied. (We hope you will be able to figure out how this could have occurred and certainly avoid any further repetition.)

The results of the leaf and water supply analysis were compiled in a letter dated July 6, 1970. After studying the soil samples further, the Lab issued another report in a letter dated July 11, 1970. The results of these tests, as reported to the Nursery, indicated that sodium toxicity was the primary cause of the plant decline.

The plants continued to decline, resulting in considerable damage to the Nursery's potted plants. The Nursery then instituted suit, alleging the negligence of the Lab caused the plant damage.

The standard of care issue is determinative of this appeal. After a review of the law and the evidence, it is our opinion that the Nursery failed to establish the requisite standard of care and the Lab's departure from such standard."

Signed by Judge

Case 2: Potatoes sprayed with iron chelate.

On July 4, 1979 two large fields of potatoes had yellow leaves and the grower received a recommendation to include iron HEDTA as an airplane foliar spray onto the fields. The application rate was 1.5 pints per acre (1.75 liters per hectare) of a solution containing $58 \mathrm{Fe}$ as FeHEDIA and the material was applied on July 18 in combination with a manzate pesticide $(2.2 \mathrm{~kg} / \mathrm{ha})$. On August 2 the $\mathrm{Fe}$ chelate treatment was repeated simultaneously with a 70-pound per acre $(78 \mathrm{~kg} / \mathrm{ha}$ ) application of $\mathrm{N}$ applied as urea. The Fe chelate and manzate were applied by airplane with about 5 gallon solution per acre (47 liters/hectare). The label recommendation was to apply that quantity of chelate but in 187 liters per hectare-a quantity of solution suitable to spraying on vegetable crops with ground equipment. 
After the second treatment the plants began to decline with severe necrosis of leaves and the owner sued because of supposed iron chelate damage. The manzate alone had not been toxic. Experts were available to testify that a concentration of $2000 \mathrm{ppm}$ Fe as FeHEDTA will burn foliage if applied as a foliar spray. The recommended rate by conventional ground application would have been $400 \mathrm{ppm} \mathrm{Fe}$. The legal case was based on the premise that the operators had applied a concentration 5 times as high as recommended. But they had applied $1 / 5$ the volume of water per unit of land so that the actual amount of Fe chelate per unit of land was exactly as that recomnended by the manufacturer. If all the foliar spray had reached $4000 \mathrm{~kg}$ of leaves (dry wt basis) per hectare, the leaf concentration would have been increased by $25 \mathrm{\mu g} \mathrm{Fe} / \mathrm{g}$ leaf. That quantity of $\mathrm{Fe}$, if 1008 absorbed by the plant, would be barely enough to correct any. deficiency and certainly not high enough to cause any toxicity.

We ran some tests with species other than potato. The old leaves of many species were not burned with 20 times as much Fe HEDTA reaching the leaf. New leaves on four of 20 plant species, however, were burned by the $20 \times$ application or $8000 \mathrm{ppm}$ Fe.

The case was settled out of court with the farmer receiving some remmeration even though we made the following points:

1. $1 \frac{1}{2} \mathrm{pts} / \mathrm{acre}$ of the iron chelate was too little for anything but isolated toxicity to leaf tip.

a. Iron quantity too low.

b. Chelate not toxic in that range.

2. The amount of spray per acre rather than the concentration is the important factor. Evaporation is so fast that a dilute spray is soon at the same concentration as a more concentrated one after application to leaves.

3. Any slight or moderate iron or iron chelate toxicity resulting from spray under normal conditions (not overdose) is reversible and plants soon recover (in a week or two).

4. The recommended procedure of 1 to $3 q \mathrm{FeSO}_{4}$ as a foliar spray also will burn tips of leaves where drops accumulate but that also is reversible if there is any plant damage.

5. The relative effectiveness of iron sulfate vs, iran chelate for foliar sprays remains controversial.

a. Iess chelate is needed than $\mathrm{FeSO}_{4}$.

b. Chelate may burn slightly more if too much used, but 50 will $\mathrm{FeSO}_{4}$.

c. Chelate depresses absorption of iron by leaves.

d. Chelate more effective after absorption than is $\mathrm{FeSO}_{4}$. 
6. The fungicide manzate is a manganese "chelate."

7. The late nitrogen application might not have helped cause the toxicity although with heavy irrigation, the preplant nitrogen could have all been leached away with resulting nitrogen deficiency by July.

a. Nitrogen deficiency interacts with iron deficiency.

b. Any biuret in urea could ruin potatoes.

8. Many things can go wrong in cropping in a hot climate with sandy soil. "Water management must be skillful." Some other problems are in deficiency, hail, diseases, insects, salt, sum scald with water drops (center pivot-irrigation was used), and restricted roots due to fertilizer banding.

Case 3: Nursery trees receiving $\mathrm{Zn}$ and Mn EDTA after budding.

Iron was not involved in the soil application in this case except that $\mathrm{FeSO}_{4}$ was applied later as a foliar spray. Three gallons of 98 $\mathrm{Zn}$ as ZnEDTA and two gallons of $68 \mathrm{Mn}$ as MEDTA were applied per acre of nursery trees (28 liters and 18.7 liters per hectare respectively). The manufacturer's recommended rate of ZnEDTA was 2 gallons per acre (18.7 liters per hectare) but 3 were used because of success in prior years with similar applications. The chelates were mixed with 15 gallons of water for each acre (140 liters per hectare). They were applied with a shank applicator on each side of the rows and $20 \mathrm{~cm}$ deep and $20 \mathrm{~cm}$ from the row.

The only item which can be contested by the grower is whether or not an application of three gallons of $\mathrm{zn}$ chelate solution containing about three pounds of zinc in place of two per acre as reconmended on the label would lead to a severe toxicity problem. The grower had previously used the material at three gallons per acre with satisfaction and the overwhelming majority of trees treated with three gallons per acre were satisfactory trees with good responses.

Relevant facts are as follows:

1. The grower applied a double dose or 6 gallons per acre of the zinc chelate to a field of young apple trees with excellent results. Our analysis indicated no zinc, manganese or iron deficiencies. There were very few leaves in the field showing iron chlorosis which is different from the previous year.

2. Most of the peach trees seen by one author in three visits in 1980 had varying degrees of iron chlorosis. Iron chlorosis intensity varies from year to year and crop losses for a given year may be different from other years. This is a complicating factor on top of the claimed chelate damage which has no relationship with the zinc and manganese applied. 
3. We were shown two fields in which chelate damage is claimed. One was a peach field and one was a cherry field. There was a pattern of tree damage especially in the peach field in which onsecutive trees in a row would be dead. The number of consecutive trees varied like 10 on one row, 40 on another, 30 on another, etc. Very seldom were there damaged plants in two rows together across from each other. The damage was random. he have proposed a hypothesis that the pattern of damage is due to root cutting by the machine used to apply the chelate which could also have exposed cut roots to the chelate solution with free access for absorption by transpirational pull.

4. There were soil problems in parts of the peach fields expecially in a field not treated with zinc chelate (because the rows were spaced 3 feet instead of the 4 feet required by the machine). Circular patches often 5 or more rows wide had poor or dying plants and this without the chelate. This control field actually had fewer marketable trees per acre than the treated field even though the treated field had spaces in the rows where the young trees had been killed supposedly by the combination of mechanized injury and the chelate simultaneously applied.

5. The zinc and manganese chelate application had reasonably desirable effects. The following are some analyses made by us of samples collected in July 1980 from treated and non-treated peach trees (leaf samples).

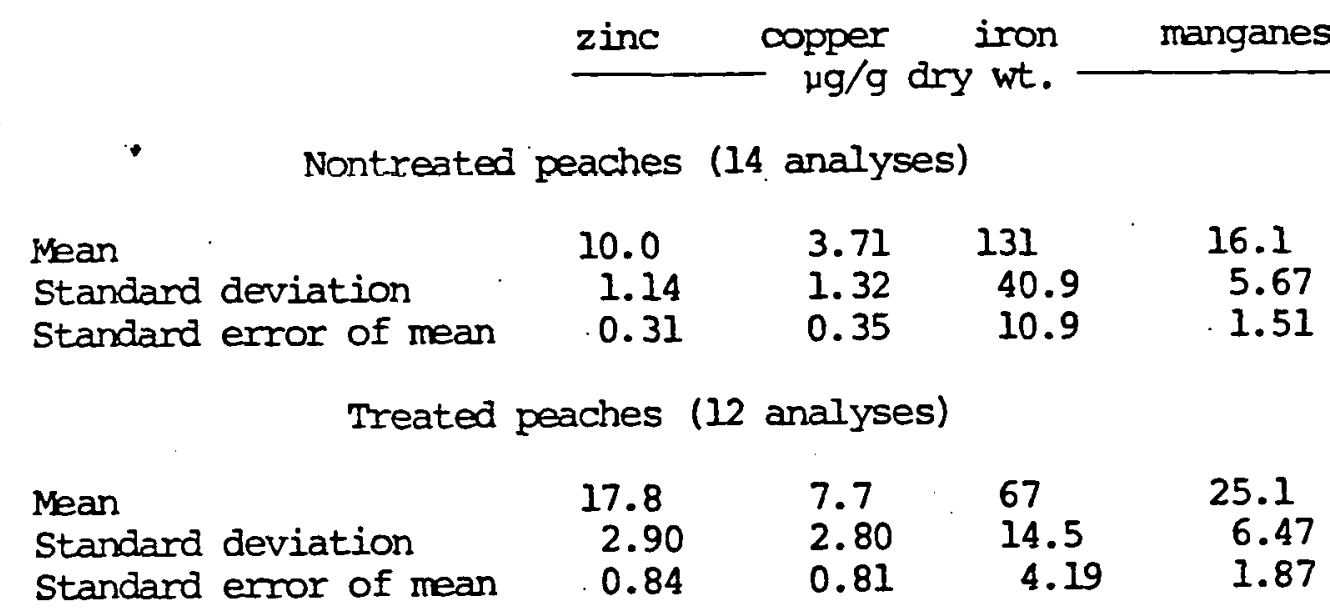

The zinc, manganese and copper status of the young trees was improved by the chelate application. Iron was decreased which is a natural consequence of zinc and manganese application. These analyses gave no indication of any excess application of micronutrients. 
Case 4: Transplant solutions with tomatoes.

In the spring of 1980 a field of tomatoes was transplanted in the Middle West by machine and by hand. The bareroot tomatoes were placed 12 inches apart in rows 4 feet apart with 1/3 cup of transplant solution containing 951 ppm N, $1250 \mathrm{ppm}$ P, 781 ppm $\mathrm{K}$ and $19 \mathrm{mg} \mathrm{Zn}$ as $\mathrm{Zn}$ EDTA, $14 \mathrm{mg} \mathrm{Mn}$ as MNEDIA and $7 \mathrm{mg}$ Fe as HEDIA. In about a week the tomato plants were dying and the leaves showed severe toxicity. A year later the grower who has a long history of success with tomatoes sued the manufacturer of the chelate for damage.

In the spring of 1981 we made a short test of adding this level of chelate in small quantities of soil in a container ( $1000 \mathrm{~g}$ soil). Roots were severely cut to simulate transplant conditions. A $2 \times$ level was also applied. One set of each treatment was kept moist by adding water to the soil. Another was kept near the dry point but not dry enough to cause wilting. After about one week the dry plants began to show stress where the chelates had been applied but not without chelate. The $2 \mathrm{x}$ showed more damage than the $1 \mathrm{x}$. Those with soil kept moist showed no damage. The dry plants showed damage only when the glasshouse became exceedingly warm- $35-38^{\circ} \mathrm{C}$ with a heat wave. Data for this

\section{TABTE I}

Leaf Analysis of Sweet-100 Tomato Plants Grown in $1000 \mathrm{~g}$ Quantities of Yolo Ioam Soil with Metal Chelates as Indicated and with Soil Kept Moist vs Soil Kelpt Dry but Without Wilting of Plants (roots were cut).

Treatment*

Leaf $\mathrm{Fe} M$ in $\mathrm{Cu}$ Al Si $\mathrm{P}$ Na $\mathrm{Ti}$ Ni dry wt. g/plant

$$
\mu \mathrm{g} / \mathrm{g}
$$

Soil moisture maintained

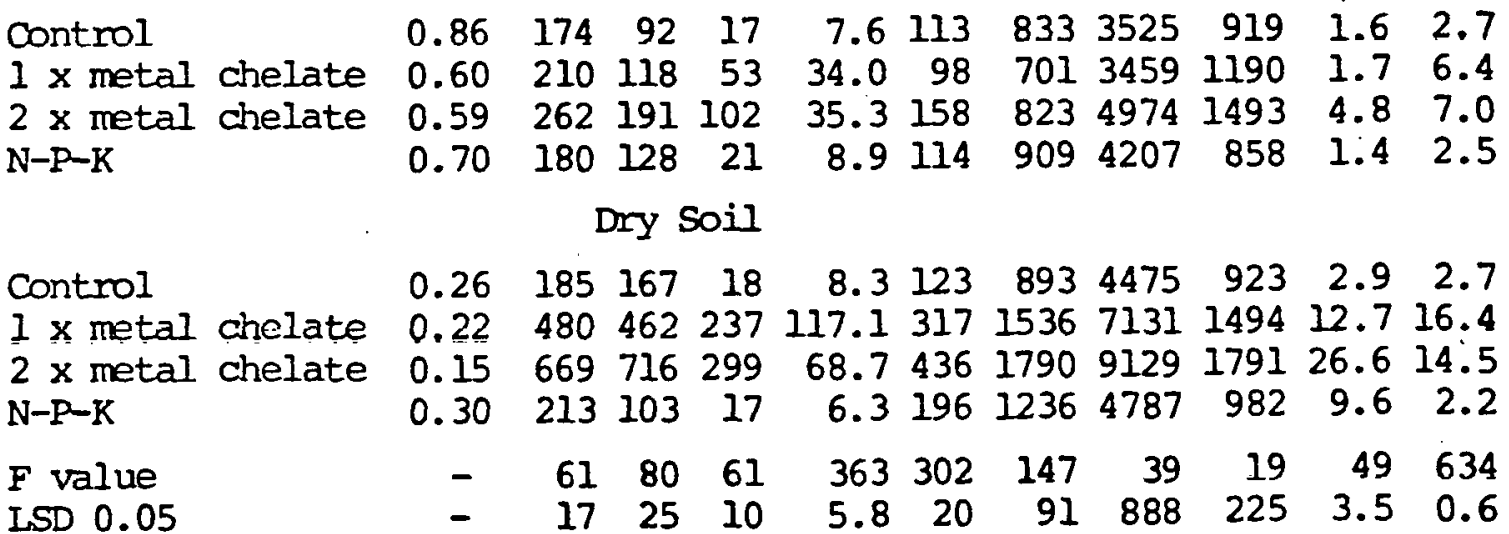

*The 1 metal chelate in $1000 \mathrm{~g}$ soil was $20 \mathrm{mg} \mathrm{zn}$ as ZnEITA, $14 \mathrm{mg} \mathrm{m}$ as MII and $7 \mathrm{mg} F$ as FeHEDIA. 
experiment are in Table 1. In the test of tomatoes in small containers the $20 \mathrm{mg} \mathrm{Zn}, 16 \mathrm{mg} \mathrm{Mn}$ and $7 \mathrm{mg} \mathrm{Fe}$ in the $200 \mathrm{ml}$ of solution applied would be 200,140 , and $70 \mathrm{\mu g} / \mathrm{ml}$ of each metal respectively if not diluted with any soil water.

This damage in the glasshouse occurred in small containers, with dry soil and with injured roots and with high air temperatures. Whether or not this simulates the field problem is not known. In the field much larger volumes of soil are available per plant and it is not likely that burning should occur as fast in the field. estimate that the concentration of $\mathrm{Zn}$ in solution in the dry soil could reach as much as $400 \mathrm{\mu g} / \mathrm{ml}$ for the $2 \times$ treatment.

\section{REFEERENCE}

Wallace, A., and R. T. Muller. 1972. Resistance of rough lemon and trifoliate orange seedlings to high levels of iron chelates. Hortscience $7(2): 121-122$. 